\title{
Living on the Outside: cultural diversity and the transformation of public space in Melbourne
}

\author{
Andrew Jakubowicz \\ University of Technology, Sydney \\ Mara Moustafine \\ University of Technology, Sydney
}

\begin{abstract}
Melbourne has been described as Australia's most liveable and most multicultural city. What relation do these descriptions have to each other? How has the public culture of Victoria been influenced by the cultural diversity of the state? The political class in Victoria has tended to be more in favour of multiculturalism as a policy, more resistant to populist racism and more positive about immigration than elsewhere in Australia. How has this orientation been affected by the institutional embedding of ethnic power during the past four decades? The organization of ethnic groups into political lobbies, which have collaborated across ethnic borders, has brought about cultural transformations in the "mainstream". Often the public experiences these transformations through changing uses of public spaces. This paper offers an historical sociology of this process, and argues for a view of public space as a physical representation of the relative power of social forces. It is based on research for the Making Multicultural Australia (Victoria) project. (http://multiculturalaustralia.edu.au ). An online version of the paper inviting user-generated comments can be found at http://mmav1.wordpress.com .
\end{abstract}

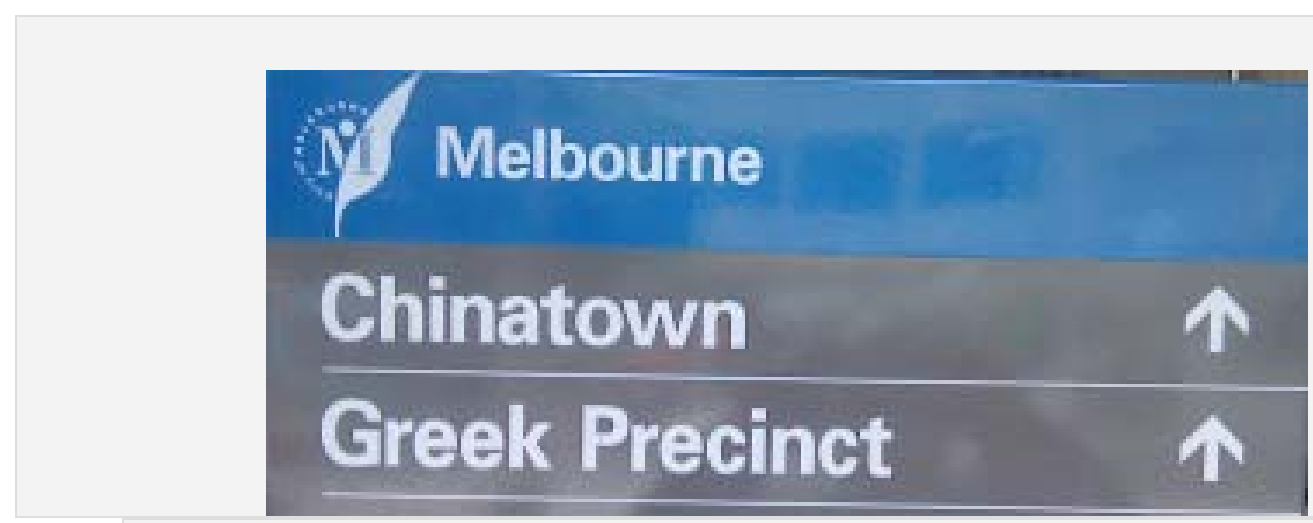

City sign pointing to Chinatown and the Greek Precinct, 2009

\section{Introduction}

The political definition of place and the political geography of space have emerged as major fields for the study of multicultural societies and the cosmopolitanisation of trans- national communities. Melbourne, state capital of Victoria in south eastern Australia, has been a site for the settlement of many generations of immigrants. While established by British settlers in the early nineteenth century, it was soon the most diverse of the colonies under the impact of the gold rushes of the 1850s. Victoria's initially open borders permitted the emergence of a 
radical political milieu that saw the arrival of Fenians from Ireland, republicans from Italy, Taiping rebels from China, escapees from Turkish domination of Greece, cameleers from the Afghan frontier, and other exiles, refugees and émigrés from the many failed rebellions of Europe. The first political struggle for democratic representation, the Eureka uprising, saw many of these groups fighting together against the colonial government. During the same period anti-Chinese feeling on the gold fields was paralleled by widespread support for Chinese miners' rights among the European and British settlers. Thus by the time of Federation, Melbourne was Australia's most cosmopolitan city, possibly its most racist, and as the seat of the first Australian parliament, its most vociferously political.

The Antipodes Festival that occurs around Russell and Lonsdale Streets in central Melbourne celebrates its contemporary claim (challenged by Toronto, and maybe true two decades ago) to be the second largest Greek city after Athens. In March 2009 Victorian Premier John Brumby announced to the crowd that $\$ 3.25$ million of State funds would be directed to "Melbourne’s iconic Greek precinct” - a majority of it towards a Greek Orthodox Community project to create an Antipodes Centre for Greek Culture, Heritage and Language. Opposition leader Ted Baillieu supported it as the first move to create a "plateia” or Greek plaza in the locality (Neos Cosmos 23/03/09). The grant was one of three to major community bodies in the city - the others being the Italian and Chinese organisations involved with the heritage of the former Italian neighbourhood of Lygon Street, and with the Chinatown area around Little Bourke Street in the city. In 2010 the Victorian government extended the program to encompass other communities (such as the Vietnamese in Richmond); in this paper we focus on the first decision and its precursor social and political changes.

In his commentary on the funding for the project, chair of the Victorian Multicultural Commission (VMC) George Lekakis noted that these were high profile projects supported by significant increases in funding for the VMC. Furthermore he said, "The Commission has played a pivotal role in bringing the communities and the key stakeholders together to develop a collaborative and visionary approach that will be beneficial in cultural, social and economic terms” (VMC Annual report 2007/8, p.34)

The commitment by the Victorian government to projects of such fairly grand scale indicates a significant growth in the degree of power and influence exerted by these ethnic 
communities in the public culture of the state. It also points to the way in which the VMC, a state agency, has positioned itself as a broker between communities and decision-makers, drawing on a widespread network of experienced political players to build coalitions in support of these innovations.

This paper traces the importance of ethnic activists and change agents in the transformation of civic and public attitudes, in this case to space and its use. In particular it examines the perceptions of participants in this process, and what they can tell us about political decisionmaking, and its responsiveness to a widening pool of ethnic stakeholders. These decisions have institutionalised an ethno-political environment created by globalisation and mass immigration over sixty years. Our analysis initially explores the experiences of immigrants who arrived at a time when national settlement policy was swinging from assimilation to integration, in the pre-dawn of multiculturalism, in the wake of the waves of Mediterranean arrivals of the 1950s and 1960s.

\section{Arriving}

The Melbourne that remains in the memory of European immigrants of the 1960s and 1970s is of a bland and silent city, where the buildings appeared to be "in mourning" and the streets empty of life. It is a city of quiet parks and gardens, of houses turned in on themselves.

Eric Lloga, an ethnic-Albanian immigrant, who arrived in Melbourne via London in the 1960s, recalls:

I found Melbourne to be a city that maybe was 20, 30 years behind anything I'd seen. Even my hometown [Ohrid in Macedonia] seemed to me to be a much more vibrant city, a much more open city. This was an empty city for the most part. People withdrew into their homes after work or into the pubs. And really there was no - nothing else that people did beyond that.... I couldn't understand why people kept their shutters closed or their curtains drawn. My first thought was that this nation must be in some kind of mourning. Because the closest experience I had to anything like what I saw in Melbourne, was when some important person died - a deputy president or some minister died so they declared a national day of mourning, so everybody would close their curtains and draw their blinds as a sign of respect.... And people like me who came out, you had these very strong feeling you were shut out. You just weren't part of that world. (E Lloga interview MMAV 2007).

Lloga went on to find work in a factory, and then managed to go to University. He became a Labor Party activist, and thirty years later emerged as a spokesman for the Albanian community in Melbourne during the Kosovo refugee crisis. For a number of years he worked for the Mayor and Council of Brunswick in inner Melbourne, where he was involved in strategy planning. 
Another community leader, Laura Mecca, who helped found and guide the Italian Historical Society, remembers her first days in Melbourne in the 1970s. She and her husband had resisted being sent to the migrant hostel in Altona, and instead after a week or so in a city hotel, moved to a flat in South Yarra.

I felt very lonely. Because being from a big city, having an extended family around you, which you know, being Italian or Greek or whatever, European, the extended family is a very important element in your life Suddenly here I was feeling completely displaced, me, my daughter, my husband. No other relatives. So I felt very lonely.... only a little girl to feed. You know, there was not much I could do. ...So I used to go into the train station, at four o'clock, at peak hour, because I went to Flinders Street and stayed there and people would - you know, touch me and push me and whatever and that felt like in Milano, I said, "Wow!” [laughs]. I used to come home, happy like anything, you know, because I'd been with the people, because here was so deserted. (L Mecca, Interview, MMAV 2007).

This sense of emptiness was echoed in other ways. Historian John Lack (2002) in his biography of Melbourne Councillor David Wang, makes special mention of Wang's awareness of the limitations of Australian public culture. He quotes Wang as saying "Part of Melbourne's problem...is its social rigidity”. Wang felt he could help transform Melbourne into a more cosmopolitan or at least a less rigid place and society. Wang was a Chinese immigrant from the late 1940s, who in the midst of White Australia and then Immigration Minister Arthur Calwell's drive to expel Asian wartime refugees, was admitted through a device masterminded by Calwell. Married to an Australian Chinese woman, Wang become a successful entrepreneur.

Meanwhile in inner city suburbs like Brunswick the flavour of public life had already been transformed. A suburb that had attracted European refugees immediately after the Second World War, and later Italian and Greek immigrants, it had a history of populist radicalism. In earlier generations it had witnessed street battles between Irish Catholic immigrants and the established Protestant working class, particularly over issues like Irish independence, and attitudes to conscription and the Great War (www.multiculturalaustralia.edu.au/doc/welcomeSydneyRdBrunswick.pdf) . In the 1930s Brunswick residents defended the free speech movement and its advocates such as artist Noel Counihan. By the 1960s it welcomed one of the first 
“non-Anglo” leaders of a Melbourne municipality, when Loreto York became the first Maltese-born mayor of an Australian city (1972) (http://catalogue.nla.gov.au/Record/1260977).

Italian immigrant Emilio Russo settled in Brunswick in the 1950s as a single man. His first accommodation as he began to establish himself was a shared house with other Italian young men. For him, the key concern was the difficulty of finding work - as he moved back and forth from Melbourne to the migrant hostel in Bonegilla, where Italian immigrants rioted at the failure of authorities to provide them with promised employment (Jakubowicz, Morrissey \& Palser 1984). For a while, he picked grapes with his brother in Mildura/Red Hill until he found work in Melbourne. By the late 1950s, his wife Maria, whom he had married in a proxy ceremony, had arrived from Italy aboard on one of the bride ships that regularly docked at Station Pier, Port Melbourne. The house they bought in Albion Street, Brunswick was home for them and their growing family of six children. Despite a return visit to Italy, the Russos decided to stay in Australia and Emilio and Maria's only move was late in life from Brunswick to a house Emilio built himself in nearby Coburg. Today he misses the honesty and security of the old Brunswick neighbourhood, the close friendships among the young migrant men and the way that precious personal space was respected.

I remember the first house, the one in Albion Street (where) I lived together with my brother. We used to work in Footscray. We used to live here, because that's where- we come here and ...-we bought a house. I remember paying the rates of the house and they - we had every week, and we used to leave the money inside the house, 16, 20 pounds - that are safe. The Sunday we don't lock the door, never-anybody used to go there. Now,ppppsh! (E Russo Interview MMAV 2007).

\section{The roots of an ethnic political coalition: political organisations}

Some key themes emerge from these interviews, which help illuminate the processes through which Melbourne changed. Melbourne was a city in which social class mattered, and in which religion and ethnicity marked boundaries of interaction. In areas like Brunswick ethnicity religion and class coalesced, feeding institutions such as the Catholic Church with all the diasporas of Catholic Europe. Brunswick was a working class area, where factories provided work especially for women (Yakka being the best-known employer) (CURA and Storer 1976, Peck 1999). In the 1960s and 1970s immigrant workers began to be more active in the unions, especially Italians after the establishment of the international FILEF (Federazione Italiana dei Lavoratori Emigrati e delle loro Famiglie). Many of the young 
people from the Italian community were influenced by European politics and the popular culture of the Left, drawn to the Eurocommunism of Italy and its strong tradition of community-based organising (Battison 2004, 2005).

Joe Caputo, now a Moreland City councillor (and former Brunswick Mayor) and a member of the VMC began his political life in the late1960s as an immigrant from Italy via South America. In the early 1970s he helped to form FILEF in Melbourne, saying of it:

if the new ... society does not accept some of those things; they can put that group at loggerheads if you like and in contrast - with the local. So in a way, we were still living the politics of Italy when we came to Australia.... Some of it, I think, not bad, because it kept us in touch with the world, but to many, because of the - because then the local society was not accepting - was not an inclusive society as such, it meant that then, thinking about Italy became like an escape, that's when it becomes negative. Because then instead of thinking of ways that one could integrate within the local society and even do benefit the local society - you then think primarily of what's happening in the country you left behind. .. Whereas if we had a much more inclusive society, I think that a lot of the Italian experience would have been blended in the Australian experience much more readily. Then you would have had the greater benefit for the Italians in that particular case and also for the Australian society in general. (J Caputo Interview MMAV 2007).

Caputo was involved in the 1970s and 1980s in the establishment of the Migrant Workers' Centre as part of the union movement in Melbourne, and played a role in struggles for English language training on the job, community languages in schools, and better occupational health and safety. It was some years later, in the wake of the dissolution of the Communist Party, that he and many like-minded migrant activists joined the Australian Labor Party. The ALP in Victoria was more left wing than elsewhere in Australia, the split of the 1950s having seen the expulsion of the more conservative Irish Catholic groups, and the consequential development of the anti-communist Democratic Labor Party, heavily influenced by Italian Australian Bob Santamaria. In other states this split did not occur, keeping the "Movement" within the ALP.

The experience of struggle in community politics and the trade unions, against the forces of conservatism and "bad" employers on the one hand, and racially-prejudiced officials in the unions on the other, produced a peculiar type of political movement. Its major fixed battles 
were strikes by migrant workers at the Ford and General Motors car companies in the 1970s, where migrant workers and the old union leadership disagreed on issue, tactics and outcomes.

Through the late 1960s and 1970s a loose coalition developed between quite diverse activists including ethnic welfare lobbyist Walter Lippmann from Australian Jewish Welfare, Greek academic George Pappadopoulos, trade unionist George Zangalis (2009) and politician Theo Sidoropoulos, and the activists associated with the Italian radical working class organization FILEF They collaborated at the community level with ethnic activists who worked closely with a number of Protestant church "street workers" - such as David Cox, Alan Matheson and Brian Howe (later ALP Social Security minister in the Hawke government), and community researchers in the Centre for Urban Research and Action (CURA) such as Des Storer (Storer 1975, CURA and Storer 1976, Jakubowicz, Morrissey \& Palser 1984, Battiston 2004, Lopez 2000) (http://www.bsl.org.au/Ecumenical-Migration-Centre-EMC.aspx).

The network that developed at that time was partly about "place" - the creation of local institutions of social development in localities of heavy immigrant settlement. However it was also ideologically integrated through a commitment to social change, and a more radical form of community development that sought to build leadership in working class poly-ethnic communities. Thirdly it was trans-class in the sense that an emerging middle-class of educated immigrants and their children were seeking to make vocal the problems raised through the lived experience of their more working class and often poorly educated confreres. While some addressed the conservative side of politics, most were more naturally drawn to the Labor Party and associated Left organisations.

Together these people became increasingly influential in drawing the ALP towards a more considered position about the place of immigrants in Australian society, and the critical issues of employment, welfare, education and health where governments were failing many immigrants and their families. Reflecting on the return of the John Cain ALP government in 1982 (until 1990 and then under Joan Kirner until 1992), political scientist James Jupp recalls the impact of the emerging ethnic political coalition on the identification of policy issues.

We went to an all-night Greek club in Sydney Road Brunswick where everybody went completely berserk, sang old communist songs, old socialist songs, jumped up and down and everyone was filled with joy. In that election the Labor Party went in with a whole complete detailed ethnic program, which 
no other party had previously done including the Labor Party. So they made a special appeal to ethnic voters, they used the ethnic language media and they had a detailed list of promises and that was an extremely important part of the election appeal. And certainly as far as the Greeks go, it was wonderful, just what they had wanted. I think also the Liberal Party, partly because of the influence of Fraser [Prime Minister 1975-1983] but also Kennett [Ethnic Affairs Minister under defeated Liberal Premier Hamer and later to be Premier in the 1990s], as well really went along with the policies, because Melbourne was certainly the place that the majority of Southern Europeans went to. Sydney did not really come on stream in the same way until the Asian and Middle Eastern arrivals in the late 1970s following the Vietnam and Lebanese wars. But Melbourne had really strongly established Greek and Italian population, Maltese population, from all over the Mediterranean area, and from Yugoslavia ... in political terms, the constituency was there, they were becoming naturalised, they were becoming politically organised, the Greeks were highly organised, they had their organisations for every island, newspapers and all the rest of it, and a politician would be foolish to ignore this.... Sensible politicians on both sides but the Labor Party had actually captured it. (J Jupp Interview MMAV 2007).

\section{Ethno-political formations: the Victorian ALP ethnic branches}

It was also during this period that the ALP agreed to the creation of ethnic branches, which by 2010 numbered 17 out of the 230 state branches. Of these, six are Greek, three Italian, and two each are from Arabic, Spanish, Macedonian and Turkish language groups. Joe Caputo sees these branches as a means of bringing immigrants into a meaningful relationship with Australian political life, though he recognises they can be used for "nastier" purposes - such as the stacking of branches in support of local community leaders, but without any real sense of commitment to the party (Allan 1978).

The ethnic branches were started in Victoria in the '70s. It started because it was felt that the reason why immigrants were not joining the Labor Party as they should be en masse, because they found - they found the structures of the Labor Party alienating because it was only done in English, it was all bureaucratic etcetera. That if you wanted to have - if you wanted to have, sort of, people from different background immigrants, you had to join the branches and ensure that they were running their own languages. That way, you would have lots of people joining and they did have that impact by the '70s, ... when the Labor Party did decide to have ethnic branches. (J Caputo Interview MMAV 2007)

Over the next quarter century these ethnic branches and the mainstream branches of the Party with now the third post-war generation of Mediterranean and other immigrant groups involved pervaded the political environment with an acceptance of cultural diversity issues.

Not everyone in the ALP was comfortable with these influences, as former Premier Steve Bracks argues: 
Some people have made a career in the Labor Party of using their ethnicity for advancement. I have made a career of not using my ethnicity for advancement. I was proud of it, pleased that I had it, it was always there - but I never used it as a lever for any particular advantage in any forum of the Party or to any elected or other position. And maybe that was to do with the longevity of my family history, maybe it's to do with an attitude, but certainly it's a view I've held. I am happy to be of Lebanese background, proud of it, but not to wear it on my sleeve, as... One of the things I think you can say is when you know you have multiculturalism working effectively and many nations, many people from many nations settling her successfully as well, and when people don't see it as anything unusual or special. When I was Premier the Lord Mayor Councillor John So was of Cantonese background, a background from China and Hong Kong, the Head of the AFL [Australian Football League] the other key position apart from the Premier and Lord Mayor, Andrew Demetriou of Cypriot background. People did not bat an eyelid, so what? They didn't get there because of their ethnic origin, they're just there because they have the abilities and capacities .... Oh, you happen to be of Chinese background or Lebanese background. That's when you know multiculturalism is mature. When it's raw, when it's rough, when it's undeveloped, is when people say, "I am a symbol, a beacon of light for my ethnic origin". That's where it's a very immature stage. (S Bracks Interview MMAV 2008).

Identity politics is, however, part of the contemporary landscape of globalising societies, and ethnic claims to recognition and resources have become as legitimate as those of any other mainstream pressure-group. These issues of identity are interwoven with other broader questions; in inner Melbourne identity politics seems to be replacing traditional class politics. Today ethno-political fissures take on serious consequences. The rising public concerns about terrorism paired with government policies on de-radicalising Muslim youth and preventing terrorism, have created in urban Australia many of the same tensions evident elsewhere (Jaggers,2008).

The transformation in the priorities of ALP parliamentary member for Brunswick Carlo Carli MP, a former FILEF activist, demonstrates what has happened to the class politics of an earlier modern Melbourne. Often issues of powerlessness are expressed in the language of culture and gender, rather than class.

Carli also notes that the types of issues that drive people have changed quite dramatically, as blue-collar factory jobs have disappeared. Political activism today is more focussed on environmental and sustainability issues and around lifestyle and identity issues, already 
beginning to become apparent during the period when he was a student rather than a politician (Carli 1982).

The issues that really are facing the generation that's between 18 and 30 and they're an intriguing generation because they do have a high level of environmental consciousness, they're political but not necessarily all that party political. They are - they do respond very strongly to issues - if you like iconic issues. And they're very, very interested in issues of lifestyle and culture. And so you know, the fact that we - to strongly support cultural programs in the area becomes quite important to ensure there's a strong cultural life, is important. (C Carli Interview MMAV 2007).

At the 2010 Federal election Melbourne (including Brunswick) was the first national seat to be captured by the Australian Greens. That transformation could be said to mark a turning point in the politics of urban space, one that had been building for the previous generation.

\section{A politics of cultural recognition and ethnic participation}

The pattern of immigrant settlement in Melbourne has generated many political centres of activity around the multitude of immigrant communities. As noted this paper concentrates on the communities associated with the first three of the ethnic enclave grants made in 2009, though the diversity of the city encompasses many other groups - Jewish, South American, Yugoslav, Turkish, Arabic, African, Indo-Chinese, to name just a few. The pathways first established by the large communities of the 19650s and 1960s have often been influenced their political trajectories, as experiences have been shared through the network of migrant resource centres set up after 1978 and the Federal Galbally Report (introduced under the Fraser Coalition government), and through peak bodies such as the Ethnic Communities Council of Victoria.

While there has been an emergent ethnic (essentially Mediterranean) working class political movement in Melbourne there has also been a reassertion by the city's long-established Chinese community of its place in the city. The dissolution of White Australia in the 1960s saw the emergence of a more assertive Chinese engagement with the city, and in particular, with the area around Little Bourke Street. With its epicentre in Celestials Lane, the area that was to become the current vibrant heart of Chinatown was then a fairly run-down and nondescript zone of decaying nineteenth century dwellings, grocery warehouses, restaurants and religious and clan buildings (Anderson, 1990; Couchman, n.d.). As the re-development of 
Chinatown was to show, the Chinese business community cultivated strong links both to the ALP and to the Liberal Party.

While the population of China-born residents declined dramatically after Federation, there were still significant numbers of Australian born Chinese with strong links to China. People such as Eunice Leong (Ching) and David Wang represented the two "ends" of this community. Eunice (married to Maurice Leong, historian of the See Yup temple in South Melbourne) traces her family story back into the nineteenth century when her grandfather was a government interpreter on the Victorian goldfields. As a young woman she lived in rural Victoria, where her father was a Chinese herbalist and she performed in a small orchestra led by her mother. During the Second World War she served in the Army and then went on to University. She remained one of the small group of Melbourne Chinese who continued to support the Peoples' Republic of China through the 1950s and 1960s, working for a time in China in the early 1970s as an English teacher at Nanjing University. Until her retirement she lectured in French at Monash University, while at the same time being an active supporter of contemporary Chinese cultural expression.

David Wang met his wife Mabel (Chen) during the Second World War when he was in Melbourne as an Intelligence Officer for the Chinese Nationalist Army. They were reunited in post-war Shanghai, and with the help of Chen family friend Immigration Minister Arthur Calwell, Wang was allowed to settle in Australia. The condition of his annual visa required him to do significant business with China. This was no mean feat for an ex-Kuomintang officer, but Wang did so, establishing the business that became the Wang Emporium. He used Calwell, that most ardent advocate of White Australia, to advance his career. There is a certain irony in Wang circumventing the intent of White Australia in the late 1940s, as Calwell intensifies its impact through the introduction of the Wartime Refugees Removal Act (1949) aimed at expelling Chinese and other refugees from Asia.

David Wang's business prospered and, in 1962, he successfully sought and gained (on appeal) an Australian passport to travel abroad. As a citizen he could then become more active in community affairs. He became a Justice of the Peace and later ran a successful campaign for Melbourne City Council, to which he was elected in 1969 becoming the first Chinese councillor). Wang began developing his proposal for a Chinatown project in 1960, 
arguing that the area should become an economic and tourist centre. He put his own money into developments there, opening the Emporium in 1964 with Calwell cutting the ribbon. As a Councillor, he advocated for a more beautiful and brighter Melbourne. His vision for Chinatown became a reality in 1976, with street arches and furniture, lighting and the creation of a Chinese New Year festival. His son, Mark Wang, is in 2010 Deputy Chair of the Chinese Museum on Cohen Place based near Celestials Lane.

Dutch scholar Jan Rath has reviewed the creation of Chinatowns around the world as part of a globalising tendency. He notes that the creation of Chinatowns as "tourist" neighbourhoods requires the coincidence of appropriate group characteristics, and the opportunity structure (Rath 2007). While David Wang experienced the absurdity of White Australia, he also saw the possibilities the society offered someone with ambition, capacity and contacts, who could endure the systemic discrimination. He also picked up on the changing politics of Melbourne, where the marginalised ethnic groups of the 1950s and 1960s were entering the mainstream of political and business life. Wang could act as a bridge between the players in the globalising region - Australian Chinese, with their long links into Asia; the emerging powerhouses of China and Hong Kong, as well as Taiwan; and the heartland of WASP Melbourne. His daughter, filmmaker Lisa Wang, whose company Black Sheep Films made the memoir documentary "Reunion" in 1998, reflects on the tension apparent in her father's ambition. She cannot understand how his drive to succeed in Australian terms still required her to remain Chinese and follow traditional Chinese values and behaviour. Viewed from outside the family, this tension seems to be a critical component of his success.

Rath points to the concept of "social embeddedness" as a way to understand how Chinatowns emerge in practice. He describes it as

the assumption that individual entrepreneurs participate in ethnically specific economic networks that facilitate their business operations (especially in acquiring knowledge, distributing information, recruiting capital and labor, and establishing relations with clients and suppliers). Social embeddedness enables entrepreneurs to reduce transaction costs by eliminating formal contracts, gaining privileged access to vital economic resources, and providing reliable expectations as to the effects of malfeasance. Particularly in cases where the entrepreneurs' primary input is cheap and flexible...(Rath 2007, p.5).

The political environment of course sets the context for the regulation of opportunity. Wang saw this early on and sought to use his political skills and networks to transform the 
impingement on him (and other Asians) of that regulatory regime. His armoury of "front" organizations did this extremely effectively - Lack’s biography notes the following committees and associations with which Wang was closely associated:

- Keep Melbourne Beautiful citizens' committee

- Make Melbourne Brighter committee

- Chinese Professional and Businessmen's Association of Victoria

- Little Bourke Street Traders

- Melbourne City Council finance and the parks, gardens and recreation sub-committees.

While Wang did face opposition to the Chinatown project, he was ultimately successful. Though he died in 1978 before the project's full realisation, his family continued to play a critical role in the installation of the Dai Loong ceremonial dragon as part of the mainstream Moomba parade from 1979.

The creation of the dragon offers a valuable insight to the inter-penetration of Australian and Chinese society. Mabel Wang tells the story of the dragon as a tale of accident and opportunity, set within the overall development of Chinatown.

Chinatown was not a definite sort of area - well it was but it was dull and very ugly in a way and there was nothing to define it. At that time the Lord Mayor was Ron Walker and he was also a great a good person who did things, was good at doing things; the Victorian government premier Mr Hamer was also very sympathetic to these sorts of things and so between the three of them it all happened. And so they put the money aside for Chinatown and they erected those arches, and fixed up the lighting, and from that time on we tried to organise the Miss Chinatown contest that finally livened up the place, and then we got a dragon. Just before he died he initiated to get a dragon for the Chinese community, and then after he died I sort of took over with another leader of the Young Chinese group who owned the original dragon, and then he asked us to help so then we, my son and I went to China, and ordered the dragon, and we raised the money and we got it here for the 25th Moomba anniversary. And ever since then we've had a Chinese New Year celebration in Chinatown and it's got bigger and bigger and it's nice now. (M Wang Interview MMAV 2007).

The traffic was not all one way. Mabel Wang recalls that the city of Foshan, near Canton, where the dragon was made, had lost the skills of dragon-making in the years since the 1949 Revolution.

My son and I went there and we had to take a drawing with us, a plan of the construction because in China they hadn't made a dragon since the cultural - 
no not no, since the communists had come into power and that was 1949, because once they were there, they stopped all these traditional things ...This was the case with anything traditional; [it] was just not continued and dragons and all that worshipping and temples and everything was not allowed. So, we had to take our diagrams back with us. And this was after the Cultural Revolution which was 1976, so if it was before 1976, we wouldn't have been able to do it. So we went there in 1978 and so we were able to get help to do that.... as a result of our dragon, I think they've made lots of dragons all over the world. (Mabel Wang Interview MMAV 2007)

\section{Ethnicity politics and public space}

Over the past decade as the second and third generation of post-war immigrants and their families have become more firmly rooted in the day-to-day multicultural realities of Melbourne, a sense of cosmopolitan style has reinvigorated the city. For sixteen years another Chinese councillor held the chair as Lord Mayor of the city. John So, Hong Kong born and from a later generation of immigrants, captured the imagination of the city's electors. At the opening of the Global Metropolis conference in Melbourne in October 2007 So waxed lyrical regarding the defining qualities of the city - in which its cultural diversity played a leading role.

Home to people from 150 countries, speaking over 200 languages, our city is one of the world's most multicultural capitals. The energy and determination of successive waves of immigrants has driven our economic goals and provide amazing quality of life we all enjoy here. Today, our city is home to a peaceful community, sharing in the many advantages multiculturalism has provided. From diverse cultural experiences to an ever- expanding network of international trade activities, our ethnic mix is paying social and economic dividends. As the city has developed, so has our understanding of how local government can play a guiding role in connecting the diverse ethnic and cultural groups. Melbourne CBD is almost unrecognisable when compared with just 20 years ago. Investment in infrastructure and changes in planning have opened up at once laneways, improved civic safety and supported an influx of unique entrepreneurial enterprises. As a result, an incredible range of retail, restaurant and entertainment experiences is now available. I think this is a good time to pay a visit to all these venues. And the 700,000 people who enter the city every day, are reminded of the positive outcomes from the city's policies of multiculturalism, accessibility and social inclusion. The city of Melbourne has also established a reputation for events, for major sporting competitions and arts festivals to ethnic celebrations. We have a year wide of different occasions celebrated here in the heart of the city for all the diverse communities. (J So Welcome, Global Metropolis conference, October 2007)

Councillor So was matched by the rhetorical excesses of the new Premier John Brumby, who replaced Bracks in 2007. Although of an Anglo background, Brumby had been deeply 
involved in Victorian Labor politics, and had been bloodied in some of the stoushes that Bracks alluded to above. He was therefore aware of the importance of the ethno-political diversity of the city to the stability of the government. Brumby positioned the debate within the framework of the nationalist rhetoric that characterised the final years of the Howard government.

If you look at the history of Australia as a whole, there have been two defining moments in our nation's history: one of course was the Anzac tradition, the birth of the Anzac tradition at Gallipoli in 1915 and the other has been postwar migration. These are the defining moments in Australian history. And you only have to look at the post-war boom to see the extraordinary strength that our community has gained from the Italian community, the Greek community, the Jewish community and a range of migrants from right across Europe. And others of course, have arrived from Vietnam, from South-East Asia, from Turkey, from Macedonia, from Iraq, Afghanistan and Africa to name just a few. ... We are considered to be in this state, one of the world's great multi-cultural melting pots. And yes, there will always be challenges to address and to overcome when we welcome new communities. But our experience here is that more than 150 years of immigration has made us socially and economically much stronger. The Economist intelligence unit has repeatedly named Melbourne as I've said as one of the world's most liveable cities and culture and diversity are key factors in that successful ranking that we enjoy.( $\mathrm{J}$ Brumby, Welcome Address, Global Metropolis Conference 2007)

\section{Class ethnicity and power in Melbourne}

There were a number of different developments in the ethno-political world of Melbourne that would lead ultimately to a commitment (yet again) of public funds to the transformation of a non-descript public space into an ethnically inflected place of cultural meaning and social interaction. These developments affected both the Liberals and the ALP.

On the conservative side of politics during the late 1990s, Howard's most effective opponent on the issue of multiculturalism and the populist racism that exploded during that period was Kennett’s Liberal government in Victoria and its few Canberra allies, like Petro Georgiou, MHR for Kooyong. Kennett re-labelled himself from minister of ethnic affairs (the Cain government title) to multicultural affairs, asserting the centrality of cultural diversity in the political operation of the state - from its economy to its cultural activities.

Middle class "ethnics” became increasingly influential. we have already seen how by the mid 1970s, David Wang was able to mobilise two of the "old guard”, Walker and Hamer, and 
deliver on his dream of a renewed or rather reinvented Chinatown. His plan proved to be an economic and cultural breakthrough, revitalising a dying part of the inner city, and reinvigorating a tourist industry that would generate thousands of jobs and prosperity for the entrepreneurs involved in it. It was also helped along by the end of racially-based immigration controls after 1972, which opened up immigration to tens of thousands of Chinese (from Hong Kong, Taiwan, Malaysia, Indonesia, as well as mainland China). The election of John So as councillor and Lord Mayor of Melbourne in 1991 was an indicator not only of their growing power, but also of the willingness of the city to accept someone as leader whom a generation before would not even have been allowed to be a resident.

Ethnically-identified localities, once enclaves, such as the Italian “end” of Lygon Street in Carlton, became a hub for other key institutions - from the Italian welfare, research and educational centre established by Co.As.It in Faraday Street, with its new museo, to the BiCentennial-funded Australian Multicultural Foundation (set up in 1988). The old Customs House near the mouth of the Yarra river, the site in the 1920s of major conflicts between Australian waterside workers and immigrant "scabs" brought in to break the strike on the waterfront, had also by 1988 been turned into the Museum of Immigration.

In the years out of power, between Cain in 1990 and Bracks in 1999, the electoral heartland of the ALP in Victoria remained firmly rooted in the ethnic working class areas of the inner city and the corridors leading to the northern and western suburbs. The ethnic branches of the ALP and the ethnic activists who were scattered through the social, educational, welfare and cultural institutions of the state, were able to gain greater purchase on the internal agendas of the Party. By the time Bracks won the 1999 state election, the young activists of the 1970s had become the more sober political players at the centre of the Victorian ALP.

Once in Government, Bracks began to re-energise the bureaucracy that he needed to implement Labor policy in the area of multicultural affairs. The Victorian Ethnic Affairs Commission (EAC) created under Cain in 1981, had been the first “ethnic” bureaucracy in Victoria. The Victorian EAC was closely identified with the ALP government, and one of Kennett's early moves was to split its powers, into a bureaucratic and political Office controlled by the Premier and a renamed Multicultural Commission with far more limited powers than before. With the return of Bracks the distinction continued, but the two bodies 
were often at loggerheads. In 2007, Bracks combined them under the Commission name, and the former Commission Chair George Lekakis (a Brunswick boy) took over direction of the overall strategy.

Lekakis, a former psychiatric nurse and social worker, had been involved in the migrant "scene" for many years. As a child he had been taken from Brunswick back to Greece, where he had tended farm animals and gone to the local school. He was in Greece during the Junta period in the 1960s, and saw the violence inflicted on socialists and democrats there. Back in Australia he worked for a while as executive officer of the Ethnic Communities Council of Victoria and as director of a Migrant Resource Centre whose chair was former Federal Labor Minister Frank Crean. These Labor contacts and his ethnic credentials prepared him for the job that Bracks gave him.

Central to Lekakis's strategy to achieve greater participation in the dynamics of government by ethnic communities was a process drawn from the radical educationist Paolo Freire, one which Lekakis refers to as “dialogue”:

You have open public meetings, where there are no agendas, other than people coming and telling us whether it's working right or wrong. And I think that's quite empowering of communities to know that they don't have to fear anybody, there is a government agency that can go out there and set up a public meeting and you can come and tell all whether the local whatever office or the local police office, or the local this office, is not doing a right - the right thing by the local community.

And therefore, I can, in a public space, make my claim or make my praise, or make a call for more resources, or say that those resources that have been provided to us through a particular program - maybe it's a neighbourhood renewal program, maybe it's a state government employment program, - is a good thing for us. Now the good/bad and whatever other commentary, positive or negative, can be made publicly and we record that and feed that back to the government.... There is a polemic about it and we work together. And I think we have been able to combine all those things to bring this about. (G Lekakis Interview MMAV 2007).

So the opening up of space is both a physical and a metaphorical process, where the space is much like the "public sphere” of political philosophers, a virtual or imaginary terrain for informed conversations among citizens (Kellner n.d). In fact the process establishing such a space requires years of effort, informed both by a theoretical understanding of organising as a 
process, and the practical realities of people engaging on difficult issues and reaching collaborative outcomes. Lekakis reflects on that process and the Commission's role, which is:

to build up a momentum of relationships and that's the critical key, in Melbourne for example, there's a network amongst people who operate welfare programs. And those relationships are formed over the last 30 or 40 years. The same thing occurs within migrant communities, the ECC set the benchmark for people to cooperate with one another, to talk, to work out problems, to advocate for reform, to support one another, to learn from one another. The same in the interfaith area. Religious leaders at local levels are coming together, so you see interfaith networks occurring everywhere. Our job is to support all that. (G Lekakis Interview MMAV 2007)

\section{Conclusion}

Melbourne has been transformed by the impact of immigration, and the cultural diversity brought in its train. The embedding of a multicultural consciousness into government and the wider society may not yet have been fully realised, yet with the extension of the ethnic precincts scheme in 2010 by another $\$ 12$ million, to refer to areas such as the Jewish sector of St Kilda, the Vietnamese in Richmond, and the Arabic sector of Coburg, it appears that the whole of the city will be dotted with government funded micro-ethnic precincts.

Nevertheless, numerous points of conflict and pockets of racism continue, especially as evidenced in the bashings of Indian students. Some refugee families, especially from African backgrounds, still experience extensive problems of settlement and adjustment (Jakubowicz 2010) while the Victorian electorate's support for immigration (once the highest in Australia) has fallen back to about the national norm (Betts 2008).

The individuals interviewed for this paper range from people who were and remain at the cutting edge of change, to those who lived through the transformations around them in the everyday world. Some were from the outset of a mind to build a new ethnic politics, and found that one of its consequences was a transformation of space and place. Others were working on class or sectoral agendas, and discovered that over time the class relations of Australia had become strongly inflected with ethnic and cultural characteristics. While class politics still remains an important dimension for the participation of working class immigrants, the context in which it takes place has become more nuanced and penetrated by cultural politics. In the process the wider Australian society has become more cosmopolitan in its appreciation of difference, and more embedded in the multiculturalism of the everyday (Wise \& Velayutham 2009). 
The celebration of diversity in public space continues - from the opening up of Melbourne's alleyways and sidewalks (recommended by the former head of the Bureau of Immigration, Multicultural and Population Research, John Nieuwenhuysen) to a more European approach to wining and dining, or to the omnipresent Asian-dominated foodhalls in shopping centres across the city. Federation Square has become something of a European piazza/plaza/plateia, offering fiestas and carnivals, once having its buildings draped with huge images from the photographic project on Australian diversity, “All of Us” . Multicultural Arts Victoria has locked in a long-term relationship with the Victorian Arts Centre, transforming the rather upmarket venue into a far more community-focussed space, reflecting the city’s diversity in music and dance. While the Victorian Ethnic Communities Council remains critical of some aspects of state government activity (and very critical of what is perceived as Federal government inaction), there is also recognition of the extraordinary success of the political organisation of ethnic communities and the mobilisation of their networks of influence over the decades.

Rath (2007) concludes his analysis of ethnic neighbourhoods by referring to the conditions under which they can flourish, and the circumstances that might render them more unlikely to become tourist attractions. He suggests that not only do the communities need to have an entrepreneurial cultural tradition, and be able to identify and take advantage of the opportunity structure they encounter, they also need to exhibit ethnic cultures that are "of interest" to the rest of society, and be both welcome and unthreatening to their new conationals. The emergence of ethnic communities as legitimate (if sometimes criticised) stakeholders in Australia's pluralist democracy has been reflected in government policy outcomes and urban infrastructure investment.

As Melbourne demonstrates, the building over time of political networks of influence remains a crucial determining factor, without which immigrants will to a greater or lesser extent remain marginalised. Thus political participation that produces real transformation in the wider social world and improvements to the physical environment may provide one of the more effective tests of the capacity of an immigrant- hosting society to integrate its incoming populations and respond creatively to their presence. For immigrant communities one of the most important outcomes of participation becomes their legitimacy in that society. 


\section{References}

Allan, L. 1978, 'Ethnic Politics - Migrant Organization and the Victorian ALP', Ethnic Studies vol. 2, no. 2, pp. 21-31

Anderson, K.J. 1990, 'Chinatown re-oriented; A critical analysis of recent redevelopment schemes in a Melbourne and Sydney enclave’, Australian Geographical Studies, vol.28, pp. 131-154.

Battison, S. 2004, 'History and Collective Memory of the Italian Migrant Workers' Organisation FILEF in 1970s Melbourne', Ph D Thesis, LaTrobe University.

Battison, S. 2005, 'Salemi v MacKellar Revisited: Drawing Together the Threads of a Controversial Deportation Case', Journal of Australian Studies, no.84.

Brunswick Oral History Project 1985, For a Better Life We Came: photographs and memories of 16 Greek and Italian migrants, Brunswick City Council, Brunswick.

Carli, C. 1982, From Ethnic Rights to the Galbally Report: the politics of multiculturalism and the Melbourne Italian community, Hons. Thesis, Political Science, University of Melbourne.

Castrique, S., Flaus, J., Stevens, T., Connolly, S., Rolls, E.C. \& Film Australia 1995, Flowers and the Wide Sea, videorecording, Film Australia, Lindfield, N.S.W.

Centre for Urban Research and Action (CURA) \& Storer, D 1976, 'But I wouldn’t want my wife to work here...': a study of migrant women in Melbourne industry, Research report for International Women's Year, CURA, Fitzroy.

Choi, C.Y. 1975, Chinese Migration and Settlement in Australia, Sydney University Press, Sydney.

Collins, J. \& P. Kunz 2009, 'Ethnicity and Public Space in the City: Ethnic Precincts in Sydney’, Cosmopolitan Civil Societies: An Interdisciplinary Journal, vol. 1, no. 1, Online (http://epress.lib.uts.edu.au/ojs/index.php/mcs/article/view/1051 ).

Couchman, S. 'Melbourne’s Chinatown - Little Bourke Street area (Victoria) (c.1854-), Online (http://www.chia.chinesemuseum.com.au/biogs/CH00015b.htm ).

Drapac, V. 2009, 'Active citizenship in multicultural Australia', Humanities Research, vol. $\mathrm{XV}$, no. 1, pp. 59-73.

Fernando, S. 2006, Race and the City: Chinese Canadian and Chinese American Political Mobilization, University of British Columbia Press, Vancouver.

Gray, G., \& Winter, C. 1997, The Resurgence of Racism : Howard, Hanson and the race debate, Department of History, Monash University, Clayton, Vic.

Hage, G. 2003, Against Paranoid Nationalism: searching for hope in a shrinking society, Pluto Press, Annandale, Vic.

Halter, M. 2000, Shopping for Identity; The Marketing of Ethnicity, Schocken Books, New York.

Jaggers, B. 2008, 'Anti-terrorism control orders in Australia and the United Kingdom: a comparison', Parliamentary Library Research Paper no.28, 2007-08, Online (http://www.aph.gov.au/library/pubs/rp/2007-08/08rp28.htm ).

Jakubowicz, A., Morrissey, M. \& Palser, J.1984, Ethnicity, Class and Social Policy, SWRC Reports and Proceedings, University of New South Wales, Kensington. 
Jakubowicz, A. 2009, 'New groups and social cohesion in Australia' in J Higley, J

Nieuwenhuysen, \& S. Neerup (eds.) Nations of Immigrants: Australia and the USA compared, Edward Elgar, Cheltenham, pp. 115-131.

Jakubowicz, A. 2010, Australia's migration policies: African dimensions, Online (http://www.humanrights.gov.au/africanaus/papers/africanaus_paper_jakubowicz.doc )

Jupp, J. 1984, Ethnic Politics in Australia, Allen \& Unwin, Sydney.

Jupp, J., Kabala, M. \& Australia, Bureau of Immigration Research 1993, The Politics of Australian Immigration, Australian Govt. Pub. Service, Canberra.

Kellner, D. n.d. 'Habermas, the Public Sphere, and Democracy: A Critical Intervention', Online http://www.gseis.ucla.edu/faculty/kellner/papers/habermas.htm

Khoo, T. 2006, Locating Asian Australian Cultures, Routledge, London.

Lack, J. 2002, 'Wang, David Neng Hwan (1920 - 1978)', Australian Dictionary of Biography, Melbourne University Press, vol. 16, pp. 483-484.

Light, I. \& Rosenstein, C. 1995, Race, Ethnicity, and Entrepreneurship in Urban America, Aldine de Gruyter, New York.

Lopez, M. 2000, The Origins of Multiculturalism in Australian Politics 1945-1975, Melbourne University Press, Melbourne.

Peck J. A. 1992 ، "Invisible threads”: homeworking, labour-market relations, and industrial restructuring in the Australian clothing trade', Environment and Planning D: Society and Space, vol. 10, no. 6, pp. 671-689.

Rath, J. (Ed.) 2000, Immigrant Businesses: The Economic, Political and Social Environment, Macmillan Press and St. Martin’s Press, Houndmills, Basingstoke, Hampshire.

Rath, J. 2007, 'The Transformation of Ethnic Neighborhoods into Places of Leisure and Consumption', Institute for Migration and Ethic Studies (IMES), University of Amsterdam Working Paper 144 January.

Storer, D. 1975, (ed) Ethnic rights, Power and Participation, CHOMI, EMC and CURA, Fitzroy.

Tan, C. 2006, “ "The Tyranny of Appearance”: Chinese Australian Identities and the Politics of Difference', Journal of Intercultural Studies, vol. 21, no. 1, pp. 65-82.

Taylor, C. \& Gutmann, A. 1994, Multiculturalism: Examining the Politics of Recognition, Princeton University Press, Princeton, N.J.

Wise, A. \& Velayutham, S. 2009, (eds.) Everyday Multiculturalism, Palgrave, London.

Zangalis, G. 2009, Migrant workers and Ethnic Communities: their Struggles for Social Justice and Cultural Rights, the Role of Greek-Australians, Common Ground, Altona.

Zappala, G. \& Australia. Dept. of the Parliamentary Library 1997, Four Weddings, a Funeral and a Family Reunion: Ethnicity and Representation in Australian Federal Politics, Dept. of the Parliamentary Library, [Canberra].

Zukin, S. 1998, 'Urban lifestyles: Diversity and standardization in spaces of consumption', Urban Studies, vol. 35nos.5-6, pp. 825-839. 